\title{
Analysis support for the design process of school buildings
}

Método de análise para o projeto de edifícios escolares

\section{Paula Roberta Pizarro Pereira \\ Doris Catharine Cornelie Knatz Kowaltowski Marcella Savioli Deliberador}

\begin{abstract}
$\mathbf{T}$

his paper presents an analysis procedure to improve school design. The procedure uses design parameters, precedent examples and comparisons for a Brazilian context. A literature review on methods and tools to analyse and evaluate architectural school design projects was undertaken. Three methods were singled out to structure the procedure. Design parameters were selected specifically for the Foundation for Educational Development (Fundação para o Desenvolvimento da Educação - FDE). The FDE manages over 5,000 public (non-private) school buildings in the State of São Paulo, Brazil. The literature on school architecture supplied the precedent examples. The procedure contains a structured design analysis method based on design parameters and comparisons between precedents and local design solutions. Tests on 34 design proposals brought to light important parameters for school design and decision-making was more transparent and efficient. The procedure broadens reflections on multidisciplinary aspects of the contemporary school environment and is seen as a design process tool for various contexts to inspire school architecture with users and learning in mind.
\end{abstract}

Keywords: School architecture. Architectural design process. Design analysis procedure.

\section{Resumo}

Este artigo apresenta um método de análise de projetos arquitetônicos escolares. Esse método utiliza parâmetros de projeto, projetos de referência e comparações para o contexto brasileiro como embasamento teórico. Apresenta-se uma revisão bibliográfica completa sobre métodos e ferramentas de análise e de avaliação dos projetos escolares. Três métodos foram selecionados para estruturar o método

Paula Roberta Pizarro Pereira Universidade Estadual de Campinas Campinas - SP - Brasil

Doris Catharine Cornelie Knatz Kowaltowski Universidade Estadual de Campinas Campinas - SP - Brasil

Marcella Savioli Deliberador Universidade de São Paulo São Paulo - SP - Brasil

Recebido em 06/03/17 Aceito em 02/08/17 proposto. Parâmetros de projeto foram selecionados, especificamente para a Fundação para o desenvolvimento da Educação (FDE), responsável por gerenciar mais de 5000 escolas públicas do Estado de São Paulo, Brasil. O método contém uma estrutura de análise de projeto, baseado nos parâmetros de projeto e em comparações entre os projetos precedentes e as soluções locais de projeto. Testes realizados com 34 propostas de projeto apresentaram que comparações possibilitam maior transparência nos parâmetros de projeto escolares e o processo de tomada de decisão mostrou-se mais eficiente. O método amplia as reflexões sobre os aspectos multidisciplinares do ambiente escolar contemporâneo e é uma ferramenta de apoio ao processo de projeto para vários contextos para inspirar uma arquitetura escolar de qualidade e com o aprendizado como foco principal.

Palavras-chaves: Arquitetura escolar. Processo de projeto. Método de análise de projeto. 


\section{Introduction}

This paper presents the results of a study on school building design analysis methods and the introduction of a procedure to improve the design process and the resulting quality of such buildings in a specific context, but shown to be appropriate for wider settings. The study is part of an on-going research project on school building design conducted at the School of Civil Engineering, Architecture and Urban Design of the University of Campinas, UNICAMP, located in the state of São Paulo, Brazil. A previous investigation of the specific design process of school buildings in this state indicated the need to evaluate and design analysis tools to improve the proposals of buildings for state-run schools (KOWALTOWSKI; DELIBERADOR, 2014).

Public ${ }^{1}$ school buildings in the state of São Paulo are managed by a foundation called the Fundação para o Desenvolvimento da Educação (FDE), responsible for the design and construction process of new schools. The FDE manages around 5,000 schools for free primary and secondary education in the state of São Paulo. An example of an FDE school is shown in Figure 1.

Buildings are based on a prefabricated building system using reinforced concrete elements. Designs are no longer stock-plans, although they are standardised. Local architectural firms are contracted to develop a project. They are given a short brief and a catalogue of architectural elements (FUNDAÇÃO..., 2015). The brief, provided by the State Secretary of Education, reflects the predominant teaching styles adopted by public schools in Brazil, based on the traditional classroom configuration (Figure 1). The quality of education is under debate in many countries, including Brazil, primarily due to low achievement rates. New objectives are discussed and these affect the physical environment demanding a reflective school design process.

The design process adopted by the FDE has a linear structure, lacking a return loop coming from evaluations at various stages of this process. A structure for an improved design process was developed to support necessary changes in the local school design scenario (KOWALTOWSKI; DELIBERADOR, 2014). This new process should no longer be linear, but include a feedback loop by mandatorily introducing analysis phases during the design and construction process of new schools. Post-Occupancy-Evaluations (POEs) of buildings in use are also essential for both retrofits and to support new designs. A programming phase needs to be introduced and supported by multidisciplinary teams, especially considering the dynamics of education and when sustainability certification is no longer an option. Additionally, design tools are necessary and procedures to inform and enrich the design process are important, especially at the programming phase to improve the quality of proposals (SANOFF, 2001; ORNSTEIN et al., 2009; PREISER; NASAR, 2014; IMMS; CLEVELAND; FISHER, 2016; GIFFORD, 2016). These should be part of participatory design processes that include a variety of methods to involve users (teachers, students, staff, parents, community representatives, specialists, consultants and designers) in productive debates on new learning environments, such as focus groups and games (WOOLNER et al., 2007; DELIBERADOR; KOWALTOWSKI, 2015).

To further support and inform an envisioned school design process this paper presents a predesign analysis procedure, based on specific parameters and precedent examples. This procedure can be incorporated into an integrated design process with the participation of a professional team consisting of designers, consultants and in this case the FDE analysts who conduct the process.

\section{Design process, procedures and precedents}

Research on the design process in architecture primarily shows that it does not follow rigid rules. The creative process is considered complex, solving what are termed wicked problems only loosely formulated, at times through a detailed architectural program (RITTEL; WEBBER, 1973).

IIn Brazil, primary and lower secondary education, called Fundamental Education, is free and compulsory for children between the ages of 6 to 14, while upper secondary education for ages 15 to 18 is also free but, not compulsory (BRASIL, 1996). The free, government supported and regulated education system is called Public Education in the country. 


\section{Figure 1 - An FDE school design example: views, plan and section of "Escola Várzea Paulista",} Courtesy: FGMF Architects
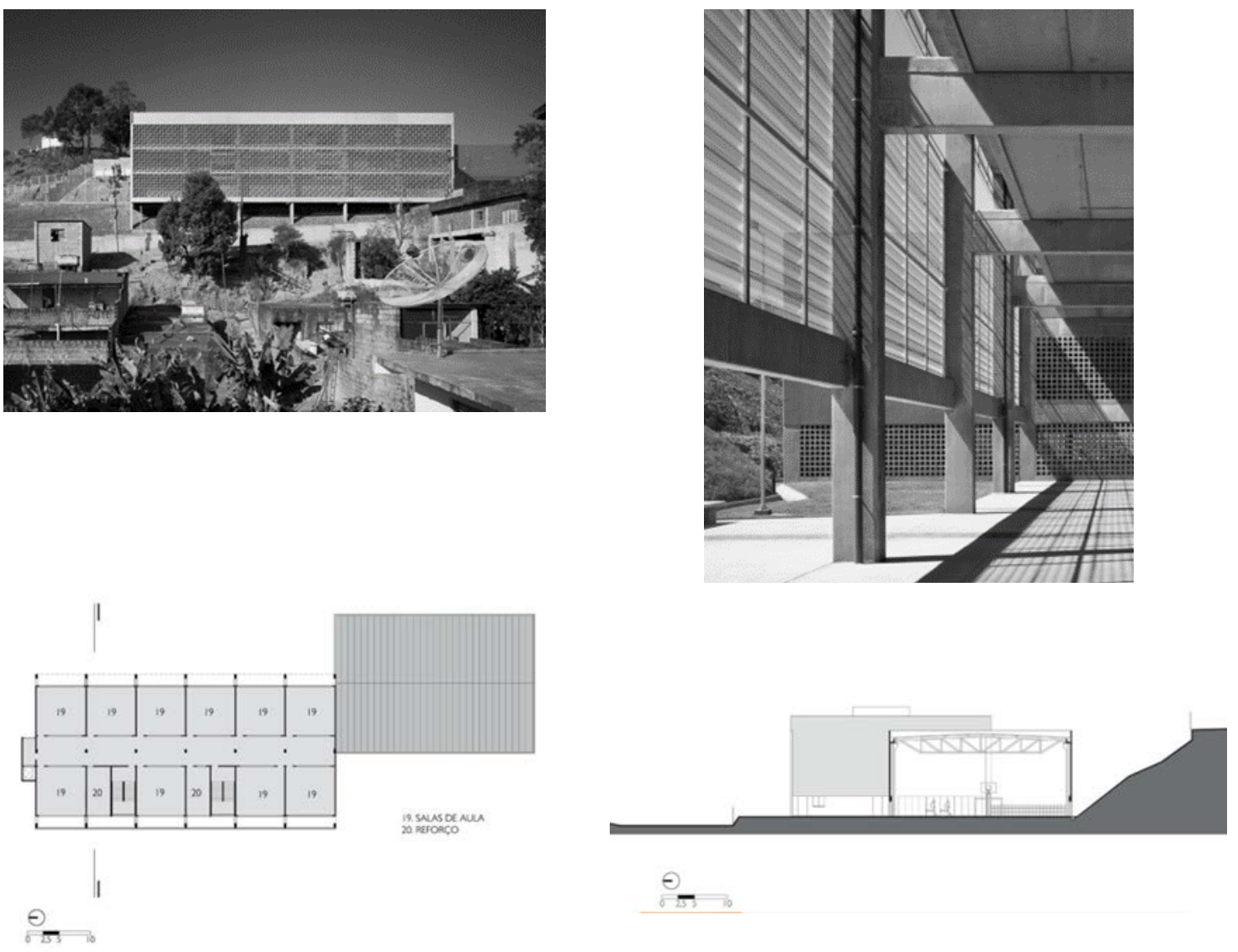

Rich data from the Design Methods Movement continues to have repercussions in diverse areas and tools to support professional activities are developed. A more structured approach to design is advocated with access to tools and procedures (CROSS, 2011). Proposals should be evaluated in relation to costs, sustainability and energy efficiency, code compliance and environmental comfort, to mention just a few of the many issues a design solution must answer to (MALLORYHILL; PREISER; WATSON, 2012). New design tools are still needed, especially to incorporate subjective issues of design. These embrace concepts, such as value judgment, as well as context and uniqueness, thus the less pragmatic expectations of any building brief (MCDONNELL; LOYD, 2014). Such tools are especially important for the design of buildings where public funds are allocated and accountability should be based on merit.

The design procedure presented here is partly based on a repertoire (precedents) of recognised design quality and can help both the experienced and the novice professional. Identifying and understanding creative solutions, their criteria and purpose, provides an important frame of reference

(AKIN, 2008; EILOUTI, 2009). There is no concrete evidence in the literature about the effect of limiting creativity based on precedents. There is evidence however that experienced architects use precedents frequently (LAWSON, 2005). Using precedents has the advantage of making it possible to combine parts of different designs, able to generate novel proposals. Precedent analysis includes specific aspects of a project that can be highlighted, often by floor-plan classification, with additional information found in the literature as shown by Van der Voordt, Vrielink and Van Wegen (1997). Access to such data has become a better support basis in the design process, due to web-based resources and available systematic ways of collecting and presenting data.

Precedent-based-design (PBD) is in line with Evidence-Based-Design (EBD). This is the process of making decisions about the built environment based on credible research to achieve the best possible outcome (CHONG; BRANDT; MARTIN, 2010). EBD has been used for school buildings (LIPPMAN, 2010). A design solution is only as good as the quality of its research and EBD is an approach in which qualitative and quantitative research informs decisions. While EBD relies 
heavily on research data, PBD uses recognised design proposals and data obtained from design analysis (BAKER, 1996; UNWIN, 2009). This data is increasingly available through web-based information systems, case studies and should be incorporated into evaluation tools (FLEMMING; AYGEN, 2001).

\section{School building design}

Discussions on the quality of school buildings go beyond questions of minimum design standards and maintaining facilities. School architecture should provide spatial qualities and positive experiences for its users, including aspects of environmental comfort. Buildings need to be designed according to the brief, educational methods and perceived socio-cultural values (FISHER, 2016). The design of public buildings must also be flexible to accommodate future needs. In the case of schools, anticipating change is related to the dynamics of education (IMMS; CLEVELAND; FISHER, 2016).

The international literature on school architecture is vast, discussing pedagogical trends with architectural responses and offering insights on an adequate design process and the application of appropriate parameters for design proposals (SANOFF, 2001; NAIR; FIELDING; LACKNEY, 2009; TAYLOR; ENGGASS, 2009; LIPPMAN, 2010; SUTHERLAND; FISCHER, 2014; WALDEN, 2015; BARRETT et al., 2016). Subjective and objective (functional and technical) questions are discussed and a safe and welcoming school is described through design parameters and case studies (FORD; HUTTON, 2007).

Evaluating the physical learning environment is important to underpin new designs, based on POE studies that apply various methods and dynamics with users (SANOFF, 2001; PREISER; NASAR, 2014). To inform the school design process, Lackney (2004) gives us an overview of issues as a list of questions that should be answered when analysing and summarising phases of a design process, evaluated using POE studies with its users for further feedback. The main issues address learning styles, health, safety, security and the well being of users. High performance and sustainable buildings, as well as integrated technology should be considered.

In Brazil, discussions on school environments are mostly based on results from POE studies, which generally show less than adequate results (ORNSTEIN et al., 2009; KOWALTOWSKI, 2011). Few studies debate the design process as the basis for such buildings. Causes of problems are rarely identified and errors are often repeated in new proposals (KOWALTOWSKI; DELIBERADOR, 2014; PEREIRA, 2013). Governments, federal, state and municipal, introduce changes in education, which in many cases can have spatial consequences. For instance, the "Whole Day School" programme, recently introduced throughout Brazil, has a serious impact on school facilities, since schools no longer divide the student population into morning and afternoon shifts, but offer a 7-hour school programme to all children from the ages of 6 to 11 years. School administrators are doing what they can to accommodate these changes, but most interventions are insufficient and demonstrate a lack of careful planning (SECRETARIA..., 2016). The FDE has also introduced a sustainability certification for all new school buildings adding a further challenge to the design process (FUNDAÇÃO..., 2014). Certification of a building is a positive step that should improve environmental conditions. Changes in the design process should address other goals with a more reflective design process that questions previous results in each new project.

\section{School design improvement procedure}

The quality of a building design depends on known and new design criteria and professional knowledge and experience or practice, as well as feedback from building performance assessments. A revision of design requirements usually takes place at the predesign stage and this is essentially an analytical activity informing the architectural programme decision-making phase. The architectural programme will not determine the design solution, but should question known practices, "seeking out problems" and serving as a reference for the design team during the design process. Essential data and quality indicators are documented to assess the design at various stages and evaluate the construction and use of a building complex (PEÑA; PARSHALL, 2001). A successful programme requires information from clients, users and a team of professionals. Furthermore, various methods can be adopted to enrich the briefing debate (GIFFORD, 2016). Relevant information from the literature, evaluation or performance assessments of buildings must be incorporated. The predesign phase, for school buildings for instance, also requires design proposal analysis and evaluations to translate educational objectives (qualitative and quantitative) into possible physical solutions.

Design evaluations will differ in nature, in accordance with the goals of such procedures. The 
topics to evaluate can range from functional, aesthetic, technical and economic or legal aspects of design. During a design process, many evaluation procedures may take place and should be performed at adequate stages to reduce costs of design redefinitions (GRAÇA; KOWALTOWSKI; PETRECHE, 2007). Design evaluation involves comparisons between different proposals or designs at various stages. Values are established and compared. Hershberger (1999) established 8 values (Human, Environmental, Cultural, Technological, Temporal, Economic, Aesthetic and Safety) for the architectural design process.

When analysing a design without judging others to compare, implicit references may be called for to recognise similarities and differences. Any judgment presupposes comparisons between the actual design under development and a reference example. Evaluations should bring to light intended impacts (as stated in the brief) and those unintended. The unintended effects, or impacts, will usually be apparent due to specific problem solving moments in the design process. The effects (intended and unintended) should be viewed in relation to context (cultural, economic, technical, environmental, etc.) and a range of different proposals under scrutiny (VOORDT; WEGEN, 2002).

Design evaluation, during the synthesis phase of the process, is usually performed in an informal manner by design teams as reflective professionals. To succeed in the task of reflection, a set of skills is applied and a lack of reflection can lead designers to explore unproductive paths. Judging the potential of references (precedents) is therefore important.

In order to support an appropriate school design process for the local Brazilian context with an analysis procedure, a literature review on design methods and tools to analyse and evaluate architectural design projects was undertaken. The aim of the review was to identify potential methods, which may be used to evaluate the specific building type (schools) within a specific context (FDE). The literature review identified evaluation methods and tools for precedent analysis (PEREIRA, 2013). The literature review singled out three methods with the potential to help develop a specific school design analysis procedure. They were the following: (a) Design Quality Indicator (DQI) ${ }^{2}$ for Schools (GANN; SALTER; WHYTE, 2003; PROGRAMME..., 2006);

(b) "Metodologia de Avaliação de Conforto Ambiental de Projetos Escolares - otimização multicritérios" Multi-criteria optimization of environmental comfort evaluation method for school buildings (MOEC) (GRAÇA;

KOWALTOWSKI; PETRECHE, 2007); and

(c) Comparative Floor-plan Analysis (CFA) (VOORDT; WEGEN, 1997).

The structure and content of DQI was analysed and compared with FDE requirements. The DQI is based on what is termed a "toolkit" consisting of a conceptual framework, a data gathering tool and a weighting mechanism to map the value of buildings in relation to their design for different uses and their ability to meet a variety of physical, aspirational and emotional needs of occupants and users (GANN; SALTER; WHYTE, 2003). The specific DQI for schools method was considered an important tool for the development of an analysis procedure for FDE conditions. DQI attributes are divided into three main themes: Impact, Function and Built Quality. Concerning Impact, the method considers: Urban and Social Integration; Internal Environment; Form, Materials, Character and Innovation. For Function: Use; Access and Space are considered important and for Built Quality: Construction; Engineering Systems and Performance. Evaluation happens through a semantic scale and aspects can be weighted for specific questions and objectives. DQI stimulates reflections on the design situation and presents itself as a rich support for the briefing stage of a project (GANN; SALTER; WHYTE, 2003).

MOEC is a method for evaluating and optimising environmental comfort parameters of school buildings at the preliminary stages of design and for the specific local (FDE) context (GRAÇA; KOWALTOWSKI; PETRECHE, 2007). Four aspects of comfort are considered: thermal, acoustic, natural lighting and functionality. Traditional classroom configurations only are included and specialists evaluate typical configurations for each comfort aspect. Results of testing FDE school designs showed that multicriteria optimisation could be used as a productive tool during the creative process. Due to the fact that school buildings in many countries follow a

${ }^{2} \mathrm{DQI}$ is a commercial product managed by: Construction Industry Council the terms of use are restricted by obligations. For these reasons the full content of DQI for School is not included in this paper. 
traditional configuration of classrooms, the method can serve other than FDE contexts as well.

CFA is based on the comparison of similar building types, in this case, schools. By comparing three essential aspects (site, building, internal spaces), a good understanding can be gained of the ways in which goals and values can be expressed in spatial solutions. POE studies, focusing on underlying arguments and user experiences of different design solutions, can give further insight into relevant points of design decisions. The idea of CFA is to base architectural design, including its programming phase, on the integration between POE data and floor plan analysis in a structured and documented way (VAN DER VOORDT; VRIELINK; VAN WEGEN, 1997).

MOEC was developed for the FDE context and, therefore, should be part of a local school design process. However, it does not include a large range of functional and more subjective aspects of design, therefore not qualifying as a school design evaluation procedure alone, as planned in this study. CFA can provide an important overview of positive and negative design solutions using comparisons. Strengths and weaknesses can then be further analysed and worked on. However, to use this method, the evaluator must have good experience and background information concerning POE studies of similar projects. The large list of concepts included in the DQI method is an important contribution to design evaluation. Access to a vast repertoire of precedent examples is also essential.

Other important issues to be considered when developing a school design procedure are those related to pedagogy and teaching styles. Most school design literature relates design considerations to pedagogical concepts, their educational goals and teaching styles. Nair (2005) lists 18 recommended learning modalities for contemporary education, shown in Figure 2. These go beyond classroom arrangements and include a variety of specific spaces. The school as a whole and its connection to the community is also part of these predesign debate considerations.

FDE designs are based on a fixed brief, a traditional classroom concept and a list of recommendations and minimum requirements. There is no participatory programming phase. Even though FDE school buildings are not based on standard designs, six plan types can be distinguished according to circulation and functional spaces (classroom/corridor) and the position of the covered sports area (gymnasium), as shown in Figure 3 (FERREIRA; MELLO, 2006).
The design improvement procedure presented here attempts to overcome some of the shortcomings of these restrictions. Improving the design of schools is important, and therefore new proposals should be analysed through both minimum standards and environmental comfort requirements and a richer context from DQI, learning modalities as well as structured comparisons (CFA) of good examples (precedents).

\section{Procedure description}

The school design analysis procedure is based on a structured process conducted within an integrated design process, as shown in the diagram in Figure 4. Participants in this process should be the client, designers, engineers and consultants from various areas. For school buildings, education specialists and school administrators should be included in pre-design debates and workshops to prepare for a participatory decision-making programming phase. For the specific case described here, FDE professionals should be the facilitators of this process.

The procedure steps are outlined here:

(a) design parameters are defined from standard FDE requirements and DQI recommendations;

(b) school designs are evaluated through the MOEC method to measure environmental comfort levels of proposals to represent the specific context of FDE school buildings. Other evaluation methods, appropriate for the early stages of a design process, may be used to assess first important decisions on form, site, orientation and location of openings for example;

(c) sample designs are selected and the sample is dimensioned. The FDE sample definition is based on examples published by the agency. The international literature on school design and case studies of high quality design solutions provides the sample of precedent examples (Design Share; AIA Top Ten Green Projects (American Institute of Architects); World Buildings Directory (Online Database) and Architectural Record Building Type Study). Precedent examples are considered benchmarks in this procedure;

(d) plan-type classification is specific for FDE, as shown in Figure 3, and precedent examples according to Figure 5;

(e) the sample is analysed according to the CFA structure (from outside - in). To adequately perform a Comparative Floor Plan Analysis (CFA), both samples (FDE and precedent examples) should be equal in number; 
(f) after this, floor plans can be analysed in relation to teaching styles and learning modalities (NAIR, 2005) and their design requirements presented in the briefs and in relation to the classroom configurations in Figure 6; and (g) this relationship is documented (as in Tables 1 and 2) for good direct comprehension of results. Both quantitative and qualitative results are evaluated at this stage.

Figure 2 - 18 learning modalities, according to Nair (2005)

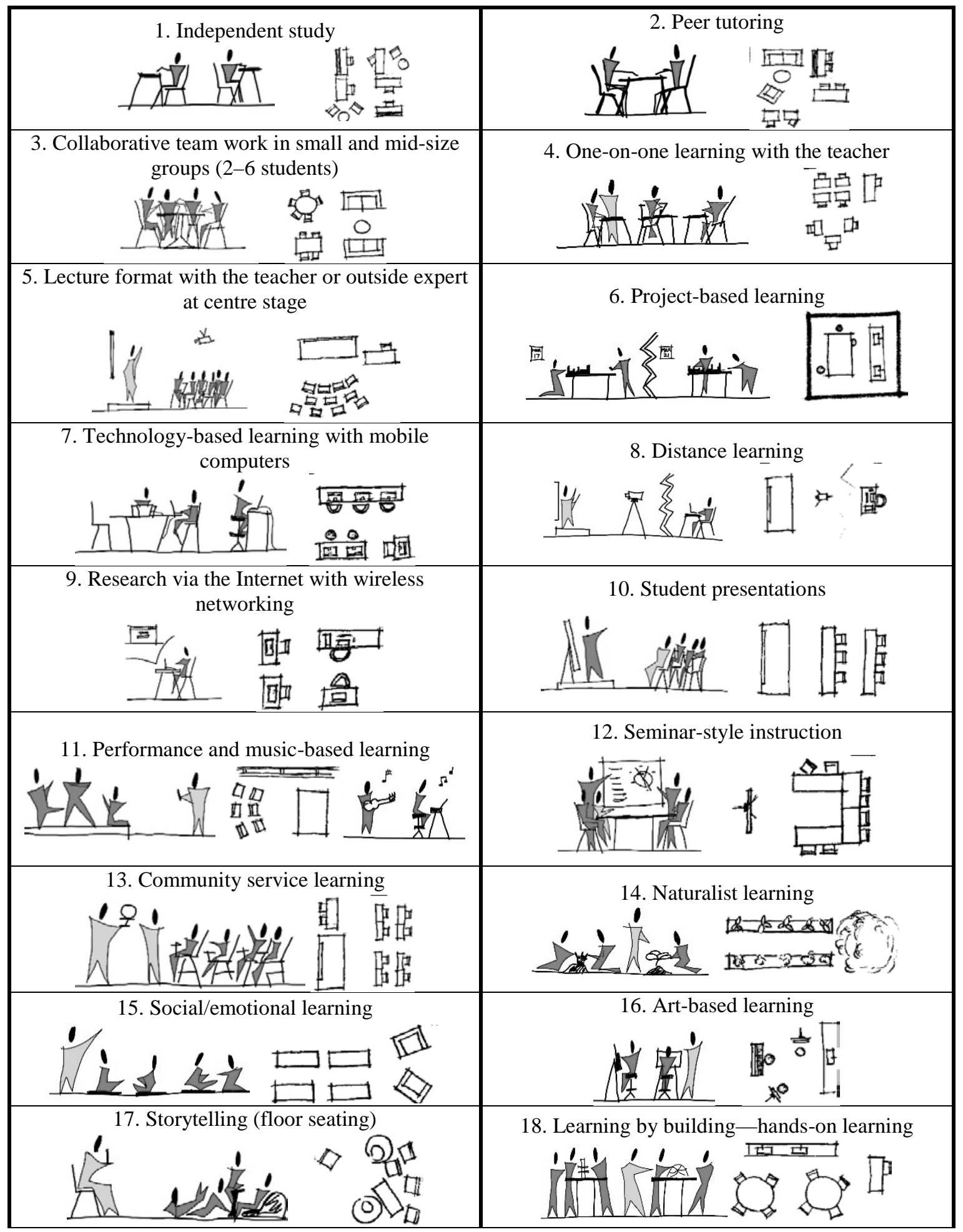

Illustration: Larissa Negris de Souza. 
Figure 3 - School plan types (FDE schools)

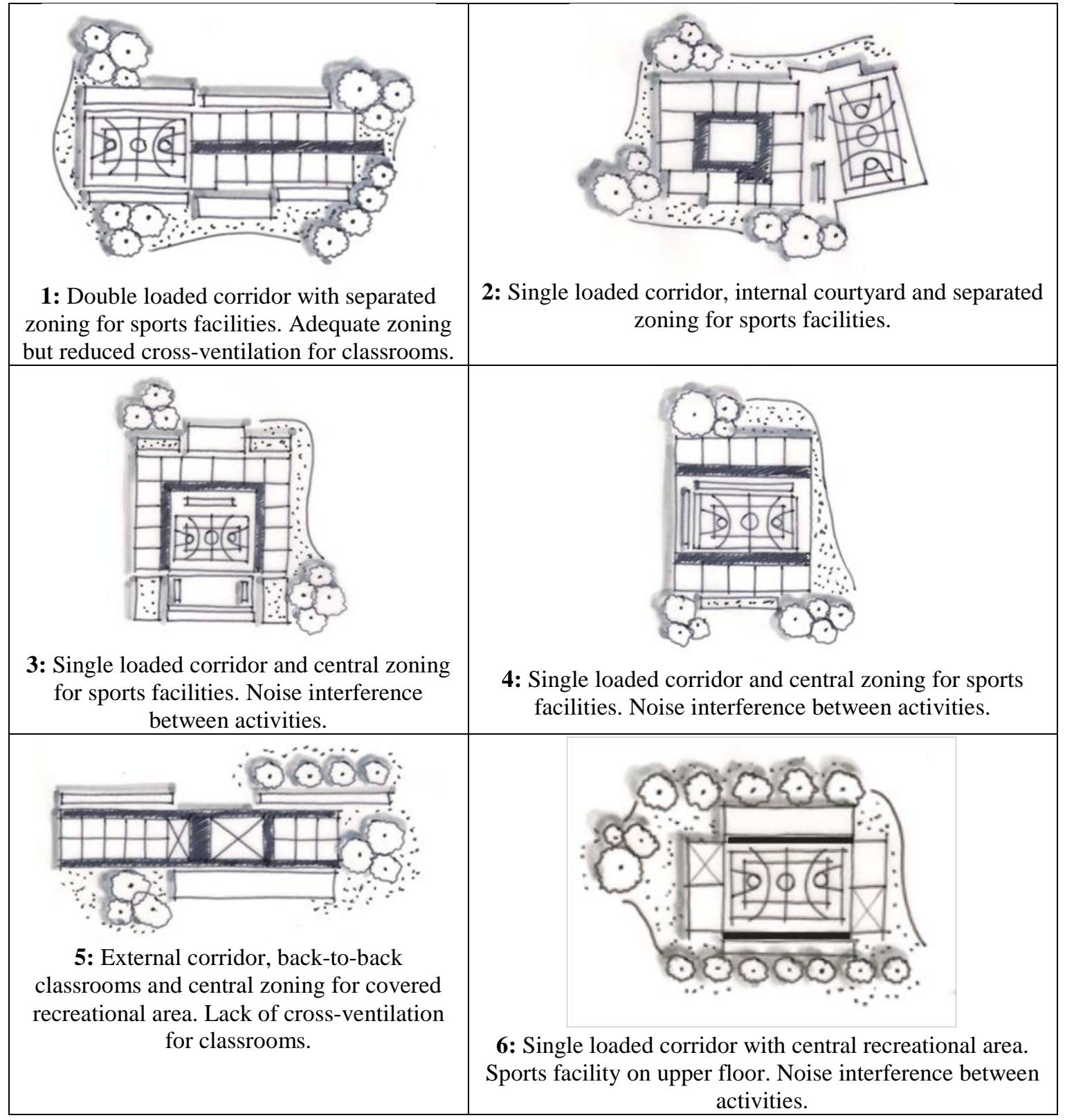

Figure 4 - School design improvement procedure diagram

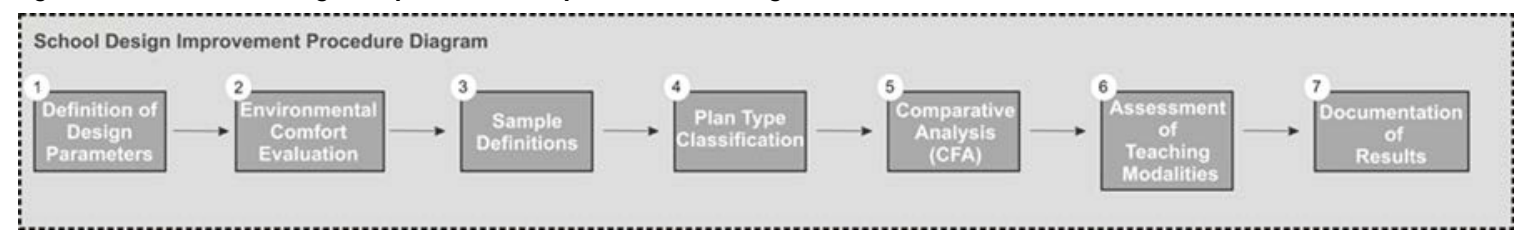

382 Pereira, P. R. P.; Kowaltowski, D. C. C. K.; Deliberador, M. S. 
Figure 5 - Plan-types of precedent examples with higher flexibility to cater for dynamics in education

\begin{tabular}{|l|l|} 
A: "L" and "Z" shaped classrooms. Informal \\
internal learning space without access to external \\
areas.
\end{tabular}

Figure 6 - Classroom configurations as found from total sample analysis

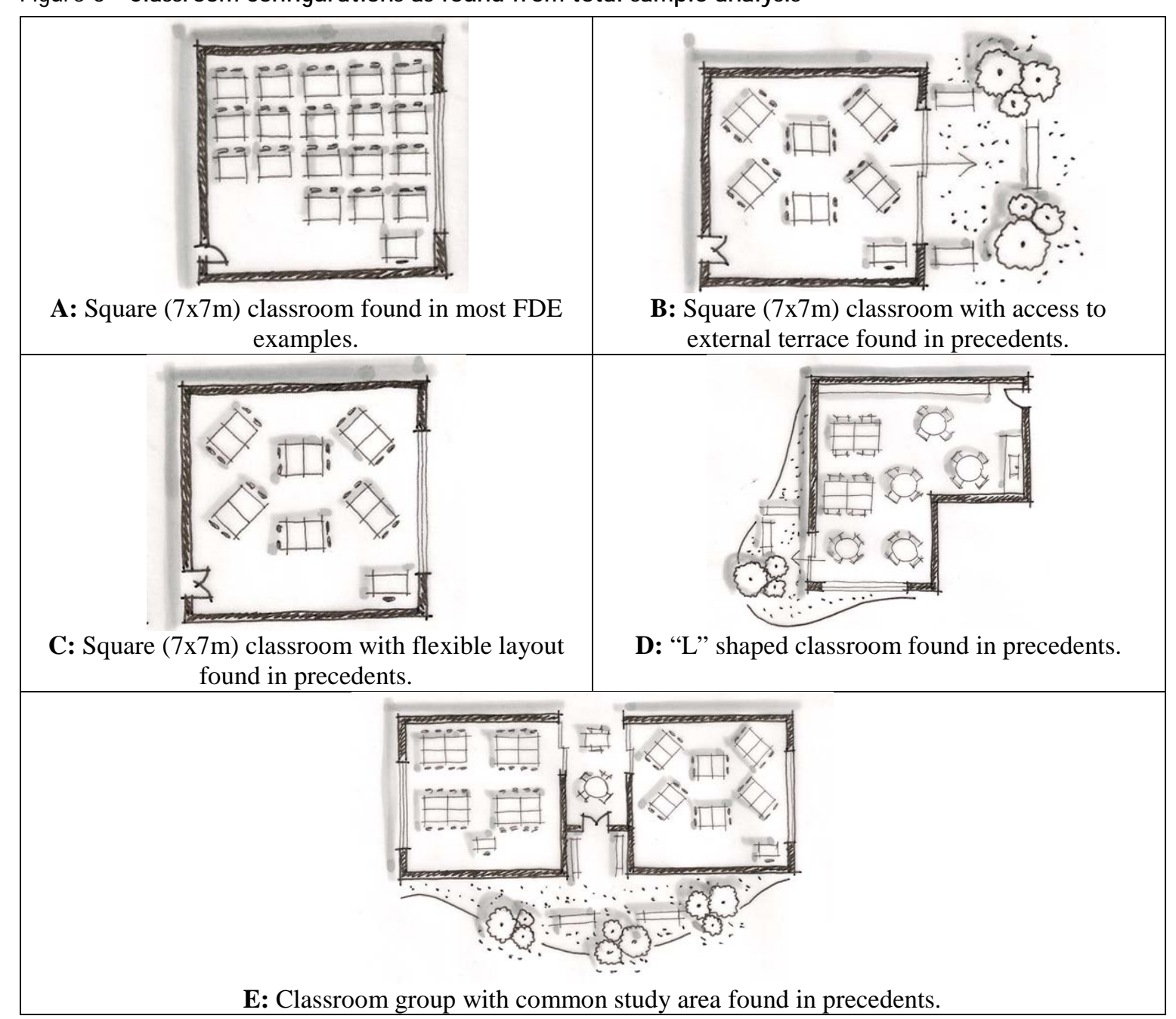


Table 1 - Quantitative results of sample analysis in relation to FDE and general requirements \& precedent recommendations: A: classrooms and corridor configuration; and B: classrooms and access to external areas

\begin{tabular}{|l|c|c|c|}
\hline Parameters: & A & B
\end{tabular}

1: FDE example with double-loaded classroom corridor

2: Precedent example of four classrooms grouped around common study area (increased learning

space)

3: FDE example of classrooms without access to external area

4: Precedent example of classrooms with access to external teaching space (transparency parameter)

General FDE requirements:

Vertical and horizontal distribution of spaces to be rationally organised

Compact solutions to minimize earth movement

Adopt modular design

Circulation flows should be straight and direct, emphasis axis, avoid obstacles and dead-end

Reduce circulation areas (max. $30 \%$ of the total built area excluding gymnasium and covered play

area)

Circulation areas with good lighting, preference for natural lighting from stairs and corridor

extremities

Minimum corridor width according to fire safety and accessibility codes. Distance from any floor leve

point to stair should be no more than $25 \mathrm{~m}$

Circulation space distribution to be adjusted to FDE structural modular dimensions

Standard FDE windows

Classrooms (7.20x7.20m) A = 51.84 $\mathrm{m}^{2}$ Min. window area = 1/10 of floor area for lighting and 1/5 of

floor area for ventilation. Acoustic isolation for privacy. Openings on opposite walls (cross

ventilation)

General functional recommendations from DQI and teaching styles and modalities:

Good zoning to minimise noise interferences

Separate student and visitor circulation patterns

Creation of a "school within an school" concept

Zoning according to different age levels

Learning spaces (alcoves) within circulation areas (corridors)

Well-related internal and external areas

All spaces are of appropriate size and form for their intended functions

Teaching and learning spaces are adequate and appropriate for the specific curriculum and organisation of the school

Space for independent study

Space for peer tutoring

Space for collaborative team work in small and mid-sized groups (2-6 students)

Sufficient space for project-based learning

Spaces for technology-based learning with laptops, tablets, etc

Spaces for wireless access to allow for online research throughout the school

Areas for storytelling (floor seating)

Outdoor spaces for naturalist learning (learning from nature)

Sufficient outdoor space for social interaction and recreation between students and the community

(weekend use of school facilities)

Make good use of available space

Small decentralised food areas

Layout for flexibility and daily space-use patterns

Good corridor (circulation spaces) supervision

Design with enhanced natural ventilation

Design with enhanced natural lighting

Design with good acoustic conditions

Design with enhanced thermal conditions

Excessive Solar radiation control

Design based on sustainability principles

Good indoor-outdoor transparency

Good indoor air quality, fresh and pleasant throughout the day, using passive means

Design based on forms and materials to provide a general overall pleasant building concept

Design that allows for social interactions, with an internal environment that offers variety, supports

concentration and encourages respect

Design with elements that set it apart

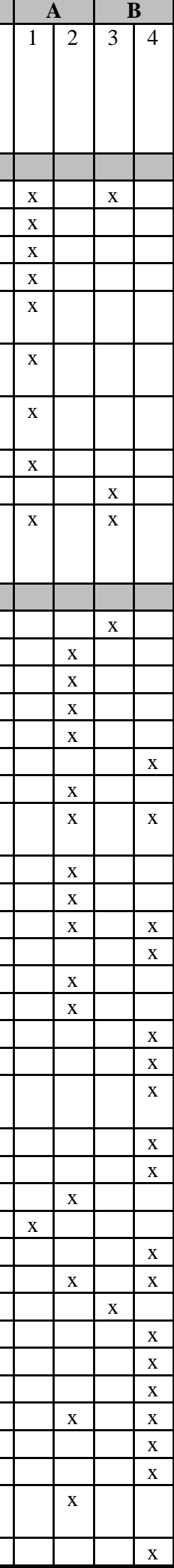

384 Pereira, P. R. P.; Kowaltowski, D. C. C. K.; Deliberador, M. S. 
Table 2 - Sample analysis in relation to five classroom configurations and FDE requirements, as well as general recommendations

\begin{tabular}{|c|c|c|c|c|c|}
\hline \multirow{2}{*}{$\begin{array}{ll} & \text { Design requirements: } \\
\text { General FDE requirements: } & \\
\end{array}$} & \multicolumn{5}{|c|}{$\begin{array}{l}\text { Classroom } \\
\text { configurations from } \\
\text { Figure } 4\end{array}$} \\
\hline & A & $\mathrm{B}$ & $\mathrm{C}$ & $\mathrm{D}$ & $\mathrm{E}$ \\
\hline Adopt modular design & $\mathrm{X}$ & & & & \\
\hline $\begin{array}{l}\text { Circulation flows should be straight and direct, emphasis axis, avoid obstacles and } \\
\text { dead-end }\end{array}$ & $\mathrm{X}$ & & & & \\
\hline Standard FDE windows & $\mathrm{X}$ & & & & \\
\hline $\begin{array}{l}\text { Classrooms ( } 7.20 \times 7.20) \mathrm{A}=51.84 \mathrm{~m}^{2} \text { Min. window area }=1 / 10 \text { of the floor area } \\
\text { for lighting and min. }=1 / 5 \text { of the floor area for ventilation. Acoustic isolation for } \\
\text { privacy. Openings on opposite walls (cross ventilation) }\end{array}$ & $\mathrm{x}$ & & & & \\
\hline $\begin{array}{l}\text { Classroom layout with tables in pairs with space for wheelchair movement for } \\
31,36 \text { or } 41 \text { students, depending on school size }\end{array}$ & $\mathrm{X}$ & & & & \\
\hline \multicolumn{6}{|l|}{ General functional recommendations from DQI and teaching modalities } \\
\hline Learning spaces (alcoves) within circulation areas (corridors) & & & & $\mathrm{X}$ & \\
\hline Well-related internal and external areas & & $\mathrm{X}$ & & $\mathrm{X}$ & \\
\hline $\begin{array}{l}\text { Teaching and learning spaces are adequate and appropriate for the specific } \\
\text { curriculum and organisation of the school }\end{array}$ & & $\mathrm{X}$ & $\mathrm{X}$ & $\mathrm{X}$ & $\mathrm{x}$ \\
\hline Space for independent study & & & & $\mathrm{X}$ & \\
\hline Space for peer tutoring & $\mathrm{X}$ & $\mathrm{X}$ & $\mathrm{X}$ & $\mathrm{X}$ & $\mathrm{x}$ \\
\hline Space for collaborative team work in small and mid-sized groups (2-6 students) & & & & $\mathrm{X}$ & $\mathrm{x}$ \\
\hline Space for lecture format with the teacher at centre stage & & & & & $\mathrm{x}$ \\
\hline Spaces for wireless access to allow for online research throughout the school & & & & $\mathrm{X}$ & \\
\hline Spaces for large group events & & & & & $\mathrm{x}$ \\
\hline Areas for storytelling (floor seating) & & & & & $\mathrm{x}$ \\
\hline Layout for flexibility and daily space-use patterns & & $\mathrm{X}$ & $\mathrm{X}$ & $\mathrm{X}$ & $\mathrm{x}$ \\
\hline Installations for special pedagogical needs & $\mathrm{x}$ & $\mathrm{x}$ & $\mathrm{X}$ & $\mathrm{X}$ & $\mathrm{x}$ \\
\hline Good visual connection between indoors and outdoors (views and transparency) & & $\mathrm{X}$ & & $\mathrm{X}$ & \\
\hline $\begin{array}{l}\text { Design that allows for social interactions, with an internal environment that offers } \\
\text { variety, supports concentration and encourages respect }\end{array}$ & & & & $\mathrm{X}$ & $\mathrm{x}$ \\
\hline Design with elements that set it apart & & $\mathrm{X}$ & & $\mathrm{x}$ & $\mathrm{X}$ \\
\hline $\begin{array}{l}\text { Total number of school projects with specific classroom configurations which } \\
\text { attend general functional recommendations }\end{array}$ & 2 & 7 & 4 & 12 & 10 \\
\hline
\end{tabular}

The procedure description is not a step-by-step method, but an indication or recommendation for how to proceed in a design proposal analysis using comparisons. Various other ways of using the concepts behind the procedure exist and may be of specific interest in a school design process.

\section{Case study test}

To illustrate the school design procedure, a test was conducted and results are shown in Tables 1 and 2. For this test, seventeen FDE examples were chosen from a publication illustrating 81 São Paulo school designs (FERREIRA; MELLO, 2006). Precedent examples were selected from recognised architectural design publications: Design Share; AIA Top Ten Green Projects (American Institute of Architects); World Buildings Directory (Online Database) and Architectural Record Building Type Study. The selection only considered those examples with complete data and full descriptions, plans, sections, elevations and images of external and internal views. Furthermore, the examples found were classified according to types of sites (rectangular and square) to allow for design analysis comparisons. To adequately perform a Comparative Floor Plan Analysis (CFA), both samples (FDE and precedent examples) had the same number of projects; in this case 17.

\section{Results and lessons learned}

The main aim of developing this analysis procedure is to support, in a structured way, the pre-design evaluation phase of a design process. School buildings need to support their pedagogical and community needs and respond to the latest Evidence Based Design recommendations. The main lessons learned from this analysis procedure are that it can be used to analyse a design proposal 
in course and precedent examples to gain information and stimulate the design process, especially in a participatory programming phase. The structured comparison enhances not only a specific design process, but the designer will gain experience and a solution repertoire. Design proposals can be justified to clients and users, especially for participatory design processes and repertoire examples can be cited. Designers are efficiently able to check the number of recommended parameters and minimum requirements a proposal complies with to establish the richness of the design, its flexibility of use and future needs.

In this test, 17 specific precedent examples were chosen. These can be expanded as new examples, and case studies become available in the literature from organisations dedicated to the investigation of effective learning environments. On a global scale, the Centre for Effective Learning Environments (CELE) from the Organisation for Economic Co-operation and Development (OECD) is an important reference. Many countries have national school building research departments such as the National Clearinghouse for Educational Facilities - USA, the Design Council - UK, and the National Institute for Educational Policy Research of Japan. Universities around the world also have groups dedicated to the study of the relation between pedagogy and space who regularly publish evidence-based findings and case studies (BARRETT et al., 2016; FISHER, 2016; IMMS; CLEVELAND; FISHER, 2016). The outlined design analysis procedure can, thus, be continually refined and enriched considering new knowledge and learning space typology tendencies.

Specific lessons were learned from the case study test. In general, plan-types and the site types (rectangular or square) were important for sample definition. The CFA recommendation to analyse designs from outside to inside, or site to interior space helped with plan-type identification and reflections on specific school building design aspects. Identifying spatial configurations that support essential teaching styles and learning modalities was facilitated.

The comparative analysis of a sample test showed that most school designs are based on specific classroom configurations, as presented in Figure 6. As a result of the test design analysis, classroom/corridor relationships were identified as shown in Figure 7. Types "A" and "B" of Figure 7 meet the FDE requirement to reduce circulation space, but do not allow for independent study or peer tutoring in circulation areas. This teaching modality is important and space for such activities will have to be found in other ways when such floor plans are adopted. In some cases, this may result in additional necessary area allocation, thus this plan type does not necessarily constitute an economic solution. Types "C" and " $D$ " of Figure 7, with generous corridors between classrooms, will offer opportunities for placing tables in circulation areas to permit individual studies, peer tutoring, collaborative group work, and even some small decentralised food areas. In the case of " $C$ " in Figure 7, natural lighting and ventilation can be optimised and “D” provides an entrance space to a set of classrooms, creating a "school within a school” concept and possible zoning for different age levels. Figure 2 also demonstrates that the FDE double loaded corridor examples only comply with one general functional recommended parameter: "good corridor supervision" and the comparative analysis demonstrated that designs based on the traditional classroom configuration (A and C) include a smaller number of recommended design parameters, indicating the review of local design criteria. The procedure also confirmed that FDE examples with classrooms lacking access to external areas attend good zoning in relation to acoustic conditions, but Table 2 demonstrates that designs based on innovative classroom configurations (B, D and E) attend a larger number of recommended design parameters. A wider range of teaching styles can be used and more learning modalities are possible. The analysis procedure could yield both quantitative and qualitative results and is effective for the analytical design process phase. Floor plan analysis in relation to design requirements presented in the briefs and in relation to the classroom configurations in Figure 5 was important to qualify design examples. The quantification of results as shown in Tables 1 and 2 facilitated comparisons. Moreover, participants of a school design project can gain experience and enhance their repertoire from documented structured and analytical comparisons.

The test analysis, both FDE and precedents, also showed that recommended classroom configurations are no longer restricted to traditional forms as shown in Figure 6. This confirms that the analysis procedure is an important design process contribution at a time when the quality of education is under debate and changes to improve the system include school architecture, learning space configurations and their detailing. 
Figure 7 - Functional and circulation space relationship (classroom/corridor) types as a result of sample analysis

\begin{tabular}{|l|l|l|l|}
\hline & \\
A: Double-loaded plan-type minimum width long \\
corridor. Poor natural lighting and ventilation \\
possibilities.
\end{tabular}

The development of the procedure and its test showed that a design process with a specific predesign analytical phase can close the loop and bring experiences from previous designs to the decision making process. The quantitative results, presented in Tables 1 and 2, as a result of a case study provided relevant indicators for specific design solutions. In a design process, both qualitative and quantitative results should be documented to form a common base for comparisons and qualitative results of a structured analysis procedure should be registered as school design recommendations.

A design process with a structured analytical phase allows programming, the next phase, to be more reflective (WOOLNER et al., 2007). Carefully analysing design examples can inform participants, in the case of schools, of diverse backgrounds and agents with different interests. Reflection on important issues can be inspired to support decision-making at the programming phase. Various participatory briefing methods (walkthroughs, focus groups, games, behavioural mapping, wish poems, simulations, among others) are recommended (SANOFF, 2001; WOOLNER et al., 2007; DELIBERADOR; KOWALTOWSKI, 2015; GIFFORD, 2016). Diverse visual representation (diagrams, drawings and sketches, models and photos, among others) of critical issues should support the debate. Attention is given to important topics of school building design. Underlying pedagogical objectives (philosophy, practices, activities, behaviours) of a project, whether for a new school or the retrofitting of an existing facility are discussed. Decisions are made on: Space Types and Standards, Layouts, Interior Design and Furniture, Circulation Flows; Accessibility and Universal Design; Environmental Comfort; Flexibility, Privacy; Safety and Security; Community Integration and Identity, as well as Integrated Technologies and Resources (ICT) and Building Infrastructure to support tendencies in education (CLEVELAND; SOCCIO, 2015).

\section{Conclusions}

To improve school buildings an architectural design analysis procedure is presented, aiming to support a reflective design process. To improve the quality of learning environments diverse factors need consideration in the debate on design. These factors are not only technical, but touch on a variety of areas: pedagogy, child development and psychology, to mention only a few of the more prevalent topics in discussions on the school environment. The diversity of pedagogical methods and the complexity of responding to the dynamics in education can no longer reduce the school environment to a string of classrooms of the 
same shape and size along a narrow corridor and the provision of some more specialised spaces such as a cafeteria and large areas for sports and recreational activities. The literature on school architecture has discussed a responsive approach to creating learning environments for some time (SANOFF, 2001). Modalities of learning and teaching styles have become the basis for a school design discussion. These debates must be valued and the analytical phase (programming or briefing) of a design process must be supported by structured information to focus on the important questions at hand

The procedure presented here is related to a specific context, which is public (non-private State administered) schools in the State of São Paulo, Brazil and the Foundation - FDE that manages the design, building and maintenance processes of around 5,000 school buildings. To date, the FDE has a linear design process based on general functional parameter and traditional learning spaces. The procedure outlined here is the result of long-standing research, by the authors, on school architecture. Many POE studies of school buildings in Brazil demonstrate that there is room for improvement and the structured procedure to analyse design proposals on a comparative basis is a contribution to support the many efforts underway to improve education in Brazil (AKKARI, 2015). The proposed improved design process is based on an extensive list of school design parameters, learning modalities and a recommended participatory programming phase. These elements can structure a productive debate and make the procedure appropriate for various contexts.

Discussions informed by structured information, often considered lacking in focus, should then reach decisions more efficiently in participatory processes (WOOLNER et al., 2007). Access to structured information is also important to support professional teams in their search for appropriate and quality design solutions. Periodic updating of this is important when new educational programmes arise with changes in teaching methods and the use of new technologies (WALDEN, 2015). Design analysis procedures, as well as evidence-based knowledge, are essential to improve the design process in a dynamic world. More appropriate school environments are envisioned, and this in turn will contribute to increasing the quality of education.

\section{References}

AKIN, O. Case Based Instruction Strategies in Architecture. Design Studies, v. 23, n. 4, p. 407431, 2008.

AKKARI, A. Improving Basic Education in Brazil. In: ZAJDA, J. (Ed.). Second International Handbook on Globalisation, Education and Policy Research. Amsterdam: Springer Netherlands, 2015.

BAKER, G. H. Design Strategies in

Architecture: an approach to the analysis of form. New York: Van Nostrand Reinhold; E \& F N Spon, 1996.

BARRETT, P. et al. The Holistic Impact of Classroom Spaces on Learning in Specific Subjects. Environment and Behavior, v. 49, n. 4, p. 425-451, 2016.

BRASIL. Lei no 9.394, de 20 de dezembro de 1996, que estabelece as diretrizes e bases da educação nacional. Diário Oficial da União, Brasília, 23 de dezembro de 1996.

CHONG, G. H.; BRANDT, R.; MARTIN, W. M.

Design Informed: driving innovation with evidence-based design. Hoboken: Wiley, 2010.

CLEVELAND, B.; SOCCIO, P. Evaluating the Pedagogical Effectiveness of Learning Spaces. Living and Learning: Research for a Better Built Environment. In: INTERNATIONAL CONFERENCE OF THE ARCHITECTURAL SCIENCE ASSOCIATION, 49., Melbourne, 2015. Proceedings... Melbourne, 2015.

CROSS, N. Design Thinking: understanding how designers think and work. Oxford: Berg Publishers, 2011.

DELIBERADOR, M. S.; KOWALTOWSKI, D. C. C. K. O Jogo Como Ferramenta de Apoio ao Programa Arquitetônico de Escolas Públicas. PARC Pesquisa em Arquitetura e Construção, v. 6, n. 2, p. 85-102, 2015.

EILOUTI, B. H. Design Knowledge Recycling Using Precedent-Based Analysis and Synthesis Models. Design Studies, v. 30, n. 4, p. 340-368, 2009.

FERREIRA, A. F.; MELLO, M. G. Arquitetura Escolar Paulista: estruturas pré fabricadas. São Paulo: FDE, IMESP, 2006.

FISHER, K. (Ed.). The Translational Design of Schools. Rotterdam: Sense Publ., 2016.

FLEMMING, U.; AYGEN, Z. A Hybrid Representation of Architectural Precedents.

Automation in Construction, v. 10, n. 6, p. 687699, 2001. 
FORD, A.; HUTTON, P. A Sense of Entry: designing the welcoming school. Mulgrave: Images Pub., 2007.

\section{FUNDAÇÃO PARA O DESENVOLVIMENTO DA EDUCAÇÃO DO ESTADO DE SÃO \\ PAULO. Catálogo de Ambientes: especificações da edificação escolar. São Paulo: Fundação Para o Desenvolvimento da Educação, 2015.}

GANN, D.; SALTER, A.; WHYTE, J. Design Quality Indicator as a Tool For Thinking. Building Research \& Information, v. 31, n. 5, p. 318-333, 2003.

GIFFORD, R. (Ed.). Research Methods for Environmental Psychology. Hoboken: WileyBlackwell, 2016.

GRAÇA, V. A. C. da; KOWALTOWSKI, D. C. C. K.; PETRECHE, J. R. D. An Evaluation Method For School Building Design at the Preliminary Phase With Optimisation of Aspects of Environmental Comfort For the School System of the State São Paulo in Brazil. Building and Environment, v. 42, n. 2, p. 984-999, 2007.

HERSHBERGER, R. G. Architectural Programming \& Predesign Manager. New York: McGraw-Hill Professional Publishing, 1999.

IMMS, W.; CLEVELAND, B.; FISHER, K. (Eds.). Evaluating Learning Environments: snapshots of emerging issues, methods and knowledge. Rotterdam: Sense Publishers, 2016.

KOWALTOWSKI, D. C. C. K. Arquitetura Escolar: o projeto do ambiente de ensino. São Paulo: Oficina de Textos, 2011.

KOWALTOWSKI, D. C. C. K.; DELIBERADOR, M. S. Understanding School Design Processes. Journal of Design Research, v. 12, n. 4, p. 280 307, 2014.

LACKNEY, J. A. Students and Teachers Tell Us What They Really Think. Tampa: DesignShare, 2004.

LAWSON, B. How Designers Think: the design process demystified. Oxford: Routledge, 2005.

LIPPMAN, P. C. Evidence-Based Design of Elementary and Secondary Schools: a responsive approach to creating learning environments. Hoboken: Wiley, 2010.

MALLORY-HILL, S.; PREISER, W. F. E.; WATSON, C. G. Enhancing Building

Performance. Hoboken: Wiley-Blackwell, 2012.

MCDONNELL, J.; LLOYD, P. Beyond Specification: a study of architect and client interaction. Design Studies, v. 35, n. 4, p. 327352, 2014.
NAIR, P. The Great Learning Street Debate. Tampa: DesignShare, 2005.

NAIR, P.; FIELDING, R.; LACKNEY, J. The Language of School Design: design patterns for the $21^{\text {th }}$ century school. $2^{\text {nd }}$. ed. Washington: National Clearinghouse for Educational Facilities, 2009.

ORNSTEIN, S. W. et al. Improving the Quality of School Facilities Through Building Performance Assessment: educational reform and school building quality in São Paulo, Brazil. Journal of Educational Administration, v. 47, n. 3, p. 350367, 2009.

PEÑA, W. M.; PARSHALL, S. A. Problem Seeking: an architectural programming primer. $4^{\text {th }}$. ed. New York: Wiley, 2001.

PEREIRA, P. R. P. Método de Análise de Precedentes Para Apoio ao Projeto da Arquitetura Escolar Pública do Estado de São Paulo. PhD Thesis - University of Campinas, Campinas, 2013.

PREISER, W. F. E.; NASAR, J. L. Assessing Building Performance: its evolution from postoccupancy evaluation. International Journal of Architectural Research: ArchNet-IJAR, v. 2, n. 1, p. 84-99, 2014.

PROGRAMME ON EDUCATIONAL BUILDING. Design Quality Indicator for Schools in the United Kingdom. [S.l]: OECD, 2006.

RITTEL, H. W. J.; WEBBER, M. M. Dilemmas in a General Theory of Planning. Policy Sciences, v. 4, n. 2, p. 155-169, 1973.

SANOFF, H. School Building Assessment Methods. Washington: National Clearinghouse for Educational Facilities U.S. Dept. of Education, Office of Educational Research and Improvement, Educational Resources Information Center, 2001.

SECRETARIA DA EDUCAÇÃO DO ESTADO DE SÃO PAULO. Ensino Integral Um dos Focos da Educação Paulista, Programas Que Oferecem Ensino Integral já Atendem 272 mil Alunos. São Paulo: SEESP, 2016.

SUTHERLAND, R.; FISCHER, F. Future Learning Spaces: design, collaboration, knowledge, assessment, teachers, technology and the radical past. Technology, Pedagogy and Education, v. 23, n. 1, p. 1-5, 2014.

TAYLOR, A. P.; ENGGASS, K. Linking Architecture and Education Sustainable Design for Learning Environments. Albuquerque: University of New Mexico Press, 2009. 
UNWIN, S. Analysing Architecture. London; New York: Routledge, 2009.

VAN DER VOORDT, T. J.; VRIELINK, D.; VAN WEGEN, H. B. Comparative Floorplan-Analysis in Programming and Architectural Design. Design Studies, v. 18, n. 1, p. 67-88, 1997.

VOORDT, D. J. M. van der; WEGEN, H. B. R. van. Ex post Evaluation of Buildings. In: DE JONG, T. M. (Ed.). Ways to Study and Research Urban, Architectural and Technical Design. Delft: DUP Science, 2002.
WALDEN, R. (Ed.). Schools For the Future: design proposals from architectural psychology. Wiesbaden: Springer, 2015.

WOOLNER, P. et al. Getting Together to Improve the School Environment: user consultation, participatory design and student voice. Improving Schools, v. 10, n. 3, p. 233-248, 2007.

\section{Acknowledgment}

The authors would like to thank FAPESP (funding agency) - Numbers: 2008/0352-0; 2013/00993-0; 2016/10871-7, for its generous support to the study presented in this paper.

\section{Paula Roberta Pizarro Pereira}

Departamento de Arquitetura e Construção, Faculdade de Engenharia Civil, Arquitetura e Urbanismo | Universidade Estadual de Campinas | Rua Albert Einstein, 951, Barão Geraldo | Campinas - SP - Brasil | CEP 13083-852 | Tel.: (19) 3521-2390 | E-mail: paulapzr@hotmail.com

\section{Doris Catharine Cornelie Knatz Kowaltowski}

Departamento de Arquitetura e Construção, Faculdade de Engenharia Civil, Arquitetura e Urbanismo | Universidade Estadual de Campinas | E-mail: doris@fec.unicamp.br

\section{Marcella Savioli Deliberador}

Departamento de Projetos, Faculdade de Arquitetura e Urbanismo | Universidade de São Paulo | Rua do Lago, 876, Butantã | São Paulo SP - Brasil | CEP 03178-200 | Tel.: (19) 99140-0230 | E-mail: marcelladeliberador@yahoo.com.br

\section{Revista Ambiente Construído}

Associação Nacional de Tecnologia do Ambiente Construído

Av. Osvaldo Aranha, 99 - 3o andar, Centro

Porto Alegre - RS - Brasil

$$
\text { CEP } 90035-190
$$

Telefone: +55 (51) 3308-4084

Fax: +55 (51) 3308-4054

www. seer. ufrgs. br/ ambienteconstruido

E-mail: ambienteconstruido@ufrgs.br 